Journal of Economic, Business and Accounting (COSTING)

Volume 2 Nomor 1, Juli-Desember 2018

e-ISSN : 2597-5234

https://doi.org/10.31539/costing.v2i1.336

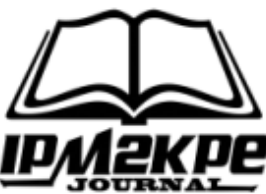

\title{
MODEL PENGUJIAN GAYA KEPEMIMPINAN, MOTIVASI KERJA MELALUI KEPUASAN KERJA TERHADAP KINERJA KARYAWAN NOTARIS DI PEKANBARU
}

\section{AN EXPERIMENTAL MODEL OF LEADERSHIP STYLE, MOTIVATION \\ THROUGH JOB SATISFACTION TOWARDS NOTARY'S EMPLOYEE SATISFACTION IN PEKANBARU}

\author{
Silvia Sari Sitompul \\ Sekolah Tinggi Ilmu Ekonomi Pelita Indonesia \\ silviasari.sitompul@yahoo.co.id
}

\begin{abstract}
Notary designation for someone who has received legal education licensed by the government to do legal matters, especially as a witness to signing the document. Objects in this study are permanent (active) employees in Notary's office Pekanbaru City. The research population is 894. Sample selection is done using probability sampling method with Simple Random Sampling technique, so that the number of samples taken was 276 employees. In this study, parametric statistics were used with multiple linear regression analysis. The results of this study indicate that leadeship style and satisfaction have significant effect on performance while work motivation has no significant effect on performance.
\end{abstract}

Keywords: Leadership Style, Work Motivation, Job Satisfaction and employee performance

\begin{abstract}
ABSTRAK
Notaris sebutan profesi untuk seseorang yang telah mendapatkan pendidikan hukum yang dilisensi oleh pemerintah untuk melakukan hal-hal hukum, khususnya sebagai saksi penandatanganan pada dokumen. Objek dalam penelitian ini adalah karyawan tetap (aktif) di kantor Notaris Kota Pekanbaru. Adapun populasi penelitan adalah 894 orang. Pemilihan sampel dilakukan dengan menggunakan metode probability sampling dengan teknik Simple Random Sampling, Sehingga didapat jumlah sampel yang akan diambil yakni sebesar276 orang. Dalam penelitian ini digunakan statistik parametrik dengan analisis regresi linier berganda. Hasil penelitian menunjukkan bahwa Gaya kepemimpinan dan Kepuasan Kerja berpengaruh signifikan terhadap kinerja, sedangkan Motivasi Kerja tidak berpengaruh signifikan terhadap kinerja.

Kata Kunci : Gaya Kepemimpinan, Motivasi Kerja, Kepuasan Kerja dan Kinerja Karyawan
\end{abstract}

\section{PENDAHULUAN}

Dalam

meningkatkan pembangunan manusia dan menghadapi persaingan bebas, perusahaan membutuhkan sumber daya manusia (SDM) dikarenakan SDM merupakan salah satu faktor yang berperan sangat penting dalam menentukan sukses atau tidaknya sebuah perusahaan. Notaris adalah Pejabat Umum yang berwenang untuk membuat Akta Otentik mengenai semua perbuatan, perjanjian, surat kuasa dan ketetapan yang diharuskan oleh peraturan perundang-undangan dan/atau 
yang dikehendaki oleh yang berkepentingan untuk dinyatakan dalam akta otentik, menjamin kepastian tanggal pembuatan akta, menyimpan akta, memberikan grosee, salinan dan kutipan akta, semuanya itu sepanjang pembuatan akta-akta itu tidak juga ditugaskan atau dikecualikan kepada pejabat lain atau orang lain yang ditetapkan oleh Undang-undang.

Kinerja karyawan dianggap sebagai apa yang dilakukan seorang karyawan dan apa yang tidak dilakukannya. Kinerja berasal dari kata job performance atau actual performance yang berarti prestasi kerja atau prestasi sesungguhnya yang dicapai oleh seseorang. Pengertian kinerja (prestasi kerja) adalah hasil kerja secara kualitas dan kuantitas yang dicapai oleh seorang pegawai dalam melaksanakan fungsinya sesuai dengan tanggung jawab yang diberikan kepadanya. Performance atau kinerja merupakan hasil atau keluaran dari suatu proses (Nurlaila, 2010). Menurut pendekatan perilaku dalam manajemen, kinerja adalah kuantitas atau kualitas sesuatu yang dihasilkan atau jasa yang diberikan oleh seseorang yang melakukan pekerjaan (Luthans, 2005). Secara observasi di lapangan dalam menyelesaikan tugas tidak tepat waktu, meninggalkan pekerjaan yang belum siap dan pandangan masyarakat atau publik menurunnya produktivitas karyawan dalam memberikan pelayanan masyarakat. Kurang baiknya pelayanan karyawan terhadap masyarakat tersebut, diperlukan adanya evaluasi dan pengawasan dari atasannya.

Mulyadi dan Rivai (2009) memaparkan bahwa pemimpin dalam kepemimpinannya perlu memikirkan dan memperlihatkan gaya kepemimpinan yang akan diterapkan kepada pegawainya dan menurut Robbins (2011) mengemukakan bahwa kepuasan kerja adalah sebagai suatu sikap umum seorang individu terhadap pekerjaannya. Pekerjaan menuntut interaksi dengan rekan sekerja dan atasan, mengikuti aturan dan kebijakan organisasi, memenuhi standar kinerja, hidup pada kondisi kerja yang sering kurang dari ideal, dan hal serupa lainnya. Ini berarti penilaian (assesment) seorang karyawan terhadap puas atau tidak puasnya dia terhadap pekerjaan. Dalam organisasi, motivasi harus mendapat perhatian yang serius bagi manajemen sumber daya manusianya. Perusahaan diharapkan dapat memenuhi kebutuhan karyawannya dan membuat karyawan merasa nyaman agar kerjasama antara karyawan dan organisasi bisa mencapai visi dan misi yang telah ditentukan.

\section{Tabel 1}

Target dan Realisasi Penyelesaian Balik Nama Sertifikat Notaris

\begin{tabular}{ccc}
\hline Tahun & Target & Realisasi \\
\hline $\mathbf{2 0 1 1}$ & 100 Hari & 100 Hari \\
\hline $\mathbf{2 0 1 2}$ & 100 Hari & 90 Hari \\
\hline $\mathbf{2 0 1 3}$ & 100 Hari & 110 Hari \\
\hline $\mathbf{2 0 1 4}$ & 100 Hari & 120 Hari \\
\hline $\mathbf{2 0 1 5}$ & 100 Hari & 180 Hari \\
\hline Sumber & Kantor & \multicolumn{2}{c}{ Notaris } \\
& Pekanbaru, 2016 \\
Pada & Tabel 1 hasil kinerja
\end{tabular}

Notaris di Pekanbaru menunjukkan kondisi kinerja karyawan yang naik turun dalam pencapaian perencanaan program kegiatan yang dilakukan. Tahun 2011 menunjukkan bahwa kinerja karyawan hampir semua Notaris di Pekanbaru memenuhi waktu realisasi yang telah ditentukan. Pada tahun 2012 hasil kinerja karyawan mengalami peningkatan dari tahun sebelumnya. Sedangkan pada tahun 2013 sampai dengan tahun 2015 hasil kinerja karyawan mengalami penurunan dimana waktu pencapaian tidak sesuai target waktu yang ditentukan. Ini 
menunjukkan hasil kinerja karyawan kurang maksimal, tidak efektif dan tidak efisiensi dalam pencapaian target yang ditentukan. Dalam Johannes Tampi (2014) dalam jurnal aplikasi manajemen dengan judul penelitian "Pengaruh Gaya Kepemimpinan dan Motivasi terhadap Kinerja Karyawan pada PT. Bank Negara Indonesia, Tbk (Regional Sales Manado)", hasil penelitian menunjukkan bahwa Gaya kepemimpinan dan motivasi kerja berpengaruh positif terhadap kinerja Karyawan. Menurut Brahmasari dan Suprayetno (2008) dengan judul Pengaruh Motivasi Kerja, Budaya Organisasi Terhadap Kepuasan Kerja Karyawan serta Dampaknya pada Kinerja karyawan (Studi kasus pada PT. Pei Hai International Wiratama Indonesia) dengan hasil motivasi kerja, budaya organisasi dan kepuasan kerja berpengaruh signifikan terhadap kinerja karyawan. Selanjutnya penelitian menunjukkan bahwa motivasi berpengaruh positif signifikan terhadap kinerja yang artinya ketika motivasi suatu perusahaan bagus maka akan membantu mendorong karyawan untuk dapat meningkatkan kinerjanya (Purwati dan Satria, 2018; Rahman, Purwati \& Yazid, 2018).

\section{Kinerja Karyawan}

Hasil kerja secara kualitas dan kuantitas dalam melaksanakan tugasnya sesuai dengan tanggung jawab yang diberikan kepadanya (Mangkunegara, 2011). Kinerja karyawan dianggap sebagai apa yang dilakukan seorang karyawan dan apa yang tidak dilakukannya. Kinerja karyawan melibatkan kualitas dan kuantitas output, kehadiran di tempat kerja, sifat akomodatif dan bermanfaat dan Ketepatan waktu output Menurut hasil penelitian yang dilakukan oleh Yang (2008) terhadap kinerja individu menunjukkan bahwa kinerja individu tidak dapat diverifikasi. Demikian pula dia menegaskan bahwa organisasi dapat menggunakan Bonus langsung dan penghargaan berdasarkan kinerja individu jika kinerja karyawan terlihat (Yang, 2008).

Menurut Amstrong dan Baron dalam Wibowo (2009) bahwa faktorfaktor yang mempengaruhi kinerja, yaitu Personal factors, Leadership factors, Team factors, System factors, Contextual/situational factors. Pengertian kinerja (prestasi kerja) adalah hasil kerja secara kualitas dan kuantitas yang dicapai oleh seorang pegawai dalam melaksanakan fungsinya sesuai dengan tanggung jawab yang diberikan kepadanya. Performance atau kinerja merupakan hasil atau keluaran dari suatu proses (Nurlaila, 2010). Menurut pendekatan perilaku dalam manajemen, kinerja adalah kuantitas atau kualitas sesuatu yang dihasilkan atau jasa yang diberikan oleh seseorang yang melakukan pekerjaan (Luthans, 2005). Menurut Robert L. Mathis dan John H. Jackson (2006), indikator kinerja adalah Kuantitas, Kualitas, Keandalan, Kehadiran, Kemampuan.

\section{Kepuasan kerja}

Kepuasan kerja yang didefinisikan oleh Wicker (2011) adalah rasa bangga dan pemenuhan diri yang diraih saat melakukan suatu hal tertentupekerjaan. Kepuasan di tempat kerja dipandang sebagai faktor penting yang sangat berkontribusiUntuk pertumbuhan organisasi. Organisasi yang sukses kebanyakan memiliki karyawan yang sangat tinggiPuas sementara kepuasan kerja yang buruk dapat melumpuhkan sebuah organisasi (Galup, Klein \& Jiang, 2008). Lee dan Ahmad (2009) menetapkan bahwa kepuasan kerja menghasilkan sering absensi, keluhan, Keterlambatan, omset tinggi dan moral yang buruk serta motivasi kerja. Faktor-faktor ini 
cenderung memiliki Dampak pada keseluruhan kinerja organisasi (Scroggins, 2008). Menurut Hasibuan (2008), indikator kepuasan kerja adalah kondisi kerja, promosi jabatan, rekan kerja, kedisiplinan dan prestasi kerja.

\section{Gaya Kepemimpinan}

Menurut Kartono (2008) :“Gaya kepemimpinan adalah sifat, kebiasaan, tempramen, watak dan kepribadian yang membedakan seorang pemimpin dalam berinteraksi dengan orang lain". Menurut Kartono (2008) indikator gaya kepemimpinan: Sifat Seorang pemimpin, Kebiasaan memegang peranan utama dalam gaya kepemimpinan, Tempramen adalah gaya perilaku seorang pemimpin dan cara khasnya dalam memberi tanggapan dalam berinteraksi dengan orang lain, Watak seorang pemimpin yang lebih subjektif, Kepribadian seorang pemimpin.

\section{Motivasi}

Motivasi adalah hal yang paling penting bagi setiap organisasi publik atau sektor swasta. Untuk Keberhasilan setiap motivasi organisasi memainkan peran penting. Semua organisasi menemukan masalah Motivasi apakah mereka berada di sektor publik atau swasta (Chintallo \& Mahadeo, 2013). Menurut Grant (2008), menetapkan bahwa karyawan termotivasi lebih lebih didorong oleh diri sendiri berbeda dengan karyawan yang kurang termotivasi. Selanjutnya, karyawan termotivasi terlibat dalam pekerjaan dan pekerjaan mereka dan lebih bersedia mengambil tanggung jawab (Kuvaas \& Dysvik, 2009). Menurut Agwu (2013) faktor motivasi yang meningkatkan motivasi karyawan yaitu Gaji dan upah yang merupakan aspek motivasional utama dan sangat penting yang mempengaruhi kinerja karyawan di Organisasi (Agwu, 2012), Bonus, Tunjangan, Keamanan kerja, Promosi.

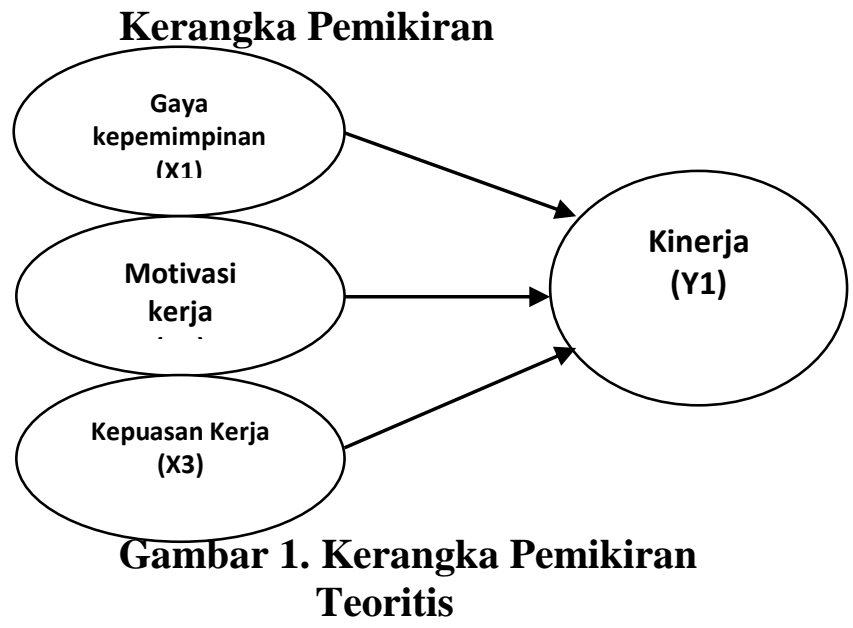

Berdasarkan kerangka pemikiran diatas, maka hipotesis dalam penelitian :

H1 Gaya kepemimpinan berpengaruh terhadap kinerja karyawan Notaris di Pekanbaru

H2 Motivasi kerja berpengaruh terhadap kinerja karyawan Notaris di Pekanbaru

H3 Kepuasan kerja berpengaruh terhadap kinerja pegawai pada Notaris di Pekanbaru

\section{METODE PENELITIAN \\ Objek dan sampel penelitian}

Objek dalam penelitian ini adalah karyawan tetap (aktif) di kantor Notaris Kota Pekanbaru.Adapun populasi penelitan adalah 894 orang.Pemilihan sampel dilakukan dengan menggunakan metode probability sampling dengan teknik Simple Random Sampling.Jumlah Ukuran Sampel ditentukan secara proporsional berdasarkan populasi karyawan masing-masing Notaris Kota Pekanbaru tersebut pada tahun 2017. Menghitung jumlah yang sampel yang akan diambil peneliti menggunakan rumus Slovin yaknijumlah sampel yang akan diambil yakni sebesar 276 orang.

\section{Jenis dan Sumber Data}

Dalam penelitian ini, penulis menggunakan data subjek, yakni berupa respon tertulis dari responden berkaitan dengan butir-butir pertanyaan atau 
pernyataan yang dielaborasi dari masing-masing indikator pada setiap variabel.Untuk itu, sumber data penelitian ini adalah sumber data primer. Untuk data yang dikhawatirkan biasa dilakukan wawancara dengan responden.

\section{Analisis Data}

\section{Analisis Deskriptif}

Menurut Sugiyono (2013) adalah suatu metode yang berfungsi untuk mendeskripsikan atau memberi gambaran terhadap obyek yang diteliti melalui data atau sampel yang telah terkumpul sebagaimana adanya tanpa melakukan analisis dan membuat kesimpulan yang berlaku untuk umum. Dalam analisis deskriptif ini akan menjelaskan tentang analisis deskriptif masing-masing variabel dan analisis deskriptif statistik. Untuk analisis deskriptif statistik akan dijelaskan tentang Mean (rata-rata) dan standar deviasi (simpangan baku).

\section{Uji Asumsi Klasik}

Dalam menganalisis data statistic parametric menggunakan regresi linier berganda perlu dilakukan uji asumsi klasik. Dengan tujuan apakah syarat uji statistic menggunakan regresi sudah terpenuhi atau belum. Adapun uji asumsi klasik yang diuji dalam penelitian ini yaitu :

\section{Uji Normalitas Data}

Menurut Ghozali (2011) uji normalitas data bertujuan untuk menguji apakah dalam model regresi, variabel independen dan dependen mempunyai distribusi normal atau tidak. Model regresi yang baik adalah distribusi data normal atau mendekati normal. Alat analisis yang dapat digunakan adalah dengan melihat tampilan plot atau data dapat juga menggunakan uji kolmogrov smirnov. Dengan kriteria pengujian, jika probabilitas lebih besar dari 0,05 maka data dalam penelitian berdistribusi normal.

\section{Uji Multikolinieritas Data}

Jika ada kecenderungan adanya multikolinier maka salah satu variabel memiliki gejala multikolinier. Pengujian adanya multikolinier ini dapat dilakukan dengan melihat nilai VIF(varians inflation factor) pada masing-masing variabel bebasnya. Jika nilai VIF nya lebih kecil dari 10 tidak ada kecenderungan terjadi gejala multikolinier. Deteksi ini menggunakan SPSS dengan analisis Collinearity Statistics.

\section{Uji Heteroskedasitas Data}

Uji heteroskedastisitas data bertujuan untuk melihat apakah ada gangguan yang diakibatkan oleh faktor dalam model tidak memiliki varians yang sama. Jika varians berbeda disebut homokedastisitas model regresiesi yang baik jika tidak terjadi heteroskedastisitas. Uji heteroskedasisitas dapat dilakukan menggunakan uji glejser. Dengan kriteria pengujian jika menunjukkan bahwa model regresi tidak terdapat gejala heteroskedastisitas, jika nilai signifikansinya lebih dari 0,05 .

\section{Uji Autokorelasi}

uji autokrelasi bertujuan untuk menguji apakah dalam model regresi linier ada korelasi antara esalahan pengganggu pada periode $t$ dengan kesalahan pengganggu pada periode $\mathrm{t}-$ (sebelumnya). masalah ini timbul karena adanya residual (kesalahan pengganggu) tak bebas dari suatu observasi ke observasi lainnya.

\section{Uji Model (Uji F)}

Menurut Ghozali 2011) menyatakan bahwa uji $\mathrm{F}$ merupakan tahapan awal mengidentifikasi model regresi yang diestimasi layak atau tidak. Layak disini maksudnya adalah model yang diestimasi layak digunakan untuk menjelaskan pengaruh variabel-variabel bebas terhadap variabel terikat. Adapun 
kriteria pengujian kelayakan model (uji F) dalam penelitian ini yaitu:

a) Jika nilai $F_{\text {hitung }}>F_{\text {tabel }}$ atau tingkat signifikansi < (alpha) 0,05 maka dapat dikatakan bahwa model regresi yang diestimasi layak

b) Jika nilai $F_{\text {hitung }}<F_{\text {tabel }}$ atau tingkat signifikansi $>$ (alpha) 0,05 maka dapat dikatakan bahwa model regresi yang diestimasi tidak layak

Uji Koefisien Determinasi $\left(\mathbf{R}^{2}\right)$

Menurut Ghazali

(2011)

mengungkapkan bahwa koefisien determinasi $\left(\mathrm{R}^{2}\right)$ pada intinya mengukur seberapa jauh kemampuan model dalam menerangkan variasi variabel dependen., Uji koefisien determinasi ini dapat dilihat dari nilai Adjusted $\mathrm{R}^{2}$ pada saat mengevaluasi mana model regresi terbaik.

Berdasarkan hal tersebut, maka dapat disimpulkan bahwa nilai Adjusted $\mathrm{R}^{2}$ tidak akan berubah apabila terdapat tambahan variabel independen yang bersifat irrelevance. Atau dengan kata lain, nilai Adjusted $\mathrm{R}^{2}$ hanya akan berubah apabila variabel independen yang ditambahkan berkaitan dengan variabel dependen pada model regresi dalam penelitian.

\section{Regresi Linier Berganda}

Adapunanalisis data yang digunakan dalam penelitian ini yaitu digunakan statistik prametrik (Jika data berdistribusi normal) dan jika data tidak berdistribusi normal maka akan digunakan analisis data statistik nonparametrik. Dalam penelitian ini digunakan statistik parametrikdengan analisis regresi linier berganda dengan bantuan software SPSS.Sehingga, dapat dibuat persamaan regresi sebagai berikut :

$\mathrm{Y}=\alpha+\beta_{1} \mathrm{X}_{1}+\beta_{2} \mathrm{X}_{2}+\beta_{3} \mathrm{X}_{3}+\beta_{4} \mathrm{X}_{4}+\mathrm{e}$

\section{Uji t (Uji Secara Parsial)}

Untuk menguji hipotesis yang digunakan dalam penelitian ini adalah uji t (uji secara parsial) pada analisis regresi. Uji $t$ adalah uji pengaruh variable independent $(\mathrm{x})$ terhadap variable dependent (y). Adapun kriteria pengujian uji t (uji secara parsial) dalam penelitian ini yaitu:

1. Jika $\mathrm{T}_{\text {hitung }}>\mathrm{T}_{\text {tabel }}$ atau Signifikasi $<$ Alpha (0.05) maka dapat diartikan bahwa variabel gender, pengalaman kerja, usia dan IPK pengaruh signifikan terhadapfinancial literacy

2. Jika $T_{\text {hitung }}<T_{\text {tabel }}$ atau Signifikasi $>$ Alpha (0.05) maka dapat diartikan bahwa variabel gender, pengalaman kerja, usia dan IPKtidak berpengaruh signifikan terhadapfinancial literacy.

\section{Analisis Hipotesis \\ Uji Validitas}

Dalam uji validitas ini untuk mendapatkan $r$ tabel dilakukan dengan melihat tabel $r$ dengan $n=276$ pada $\alpha=$ 5\% dengan uji dua sisi sehingga di dapat $r$ tabel sebesar 0,118. Apabila $r$ hitung $>\mathrm{r}$ tabel $=$ Valid dan $\mathrm{r}$ hitung $<\mathrm{r}$ tabel $=$ Tidak Valid. Hasil uji validitas selengkapnya dapat dilihat pada tabel sebagai berikut :

\section{Tabel 2}

Uji Validitas Variabel Bebas (X1) Gaya Kepemimpinan

\begin{tabular}{|c|c|c|c|c|}
\hline Variabel & $\begin{array}{l}\text { No. } \\
\text { Butir }\end{array}$ & $\begin{array}{l}\mathbf{r} \\
\text { Hitung }\end{array}$ & $\begin{array}{l}\mathbf{r} \\
\text { Tabel }\end{array}$ & Keputusan \\
\hline \multirow{5}{*}{ 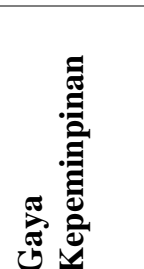 } & 1 & 0,595 & 0,118 & Valid \\
\hline & 2 & 0,884 & 0,118 & Valid \\
\hline & 3 & 0,770 & 0,118 & Valid \\
\hline & 4 & 0,935 & 0,118 & Valid \\
\hline & 5 & 0,935 & 0,118 & Valid \\
\hline
\end{tabular}

bahwa untuk setiap butir variabel Gaya Kepemimpinan semuanya valid, karena korelasi butir $r$ hitung diatas $r$ tabel, sehingga dapat di ikut sertakan dalam penelitian. 
Tabel 3

Uji Validitas Variabel Bebas (X2) Motivasi Kerja

\begin{tabular}{|c|c|c|c|c|}
\hline Variabel & $\begin{array}{l}\text { No. } \\
\text { Butir }\end{array}$ & $\begin{array}{l}\mathbf{r} \\
\text { Hitung }\end{array}$ & $\begin{array}{l}\mathbf{r} \\
\text { Tabel }\end{array}$ & Keputusan \\
\hline \multirow{5}{*}{ 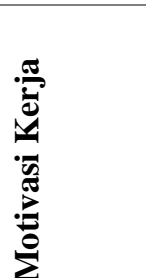 } & 1 & 0,693 & 0,118 & Valid \\
\hline & 2 & 0,648 & 0,118 & Valid \\
\hline & 3 & 0,750 & 0,118 & Valid \\
\hline & 4 & 0,818 & 0,118 & Valid \\
\hline & 5 & 0,818 & 0,118 & Valid \\
\hline
\end{tabular}

Sumber : Hasil Olahan SPSS

Dari tabel diatas dapat diketahui bahwa untuk setiap butir variabel motivasi kerja semuanya valid, karena korelasi butir $\mathrm{r}$ hitung diatas $\mathrm{r}$ tabel, sehingga dapat di ikut sertakan dalam penelitian.

\section{Tabel 4}

Uji Validitas Variabel Bebas (X3) KepuasanKerja

\begin{tabular}{|c|c|c|c|c|}
\hline Variabel & $\begin{array}{l}\text { No. } \\
\text { Butir }\end{array}$ & $\begin{array}{l}\mathbf{r} \\
\text { Hitung }\end{array}$ & $\begin{array}{l}\mathbf{r} \\
\text { Tabel }\end{array}$ & Keputusan \\
\hline \multirow{5}{*}{ 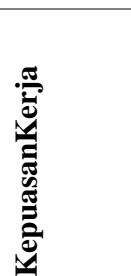 } & 1 & 0,886 & 0,118 & Valid \\
\hline & 2 & 0,797 & 0,118 & Valid \\
\hline & 3 & 0,749 & 0,118 & Valid \\
\hline & 4 & 0,733 & 0,118 & Valid \\
\hline & 5 & 0,824 & 0,118 & Valid \\
\hline
\end{tabular}

bahwa untuk setiap butir variabel Kepuasankerja semuanya valid, karena korelasi butir $\mathrm{r}$ hitung diatas $\mathrm{r}$ tabel, sehingga dapat di ikut sertakan dalam penelitian.

Tabel 5

\section{Uji Validitas Variabel Terikat (Y)} Kinerja Pegawai

\begin{tabular}{lllll}
\hline Variabel & $\begin{array}{l}\text { No. } \\
\text { Butir }\end{array}$ & $\begin{array}{l}\mathbf{r} \\
\text { Hitung }\end{array}$ & $\begin{array}{l}\mathbf{r} \\
\text { Tabel }\end{array}$ & Keputusan \\
\hline \multirow{2}{*}{} & 1 & 0,859 & 0,118 & Valid \\
\cline { 2 - 5 } & 2 & 0,512 & 0,118 & Valid \\
\cline { 2 - 5 } & 3 & 0,731 & 0,118 & Valid \\
\cline { 2 - 5 } & 4 & 0,810 & 0,118 & Valid \\
\hline \multirow{2}{*}{} & 5 & 0,505 & 0,118 & Valid \\
\hline
\end{tabular}

Sumber : Hasil Olahan SPSS

Dari tabel diatas dapat diketahui bahwa untuk setiap butir variabel kinerja pegawai semuanya valid, karena korelasi butir $\mathrm{r}$ hitung diatas $\mathrm{r}$ tabel, sehingga dapat di ikut sertakan dalam penelitian.

\section{Uji Reabilitas}

Uji reliabilitas digunakan untuk mengetahui apakah indikator yang digunakan dapat dipercaya atau handal sebagai alat ukur variabel. Maksud dari dapat dipercaya atau handal adalah konsistensi hasil pengukuran jika dilakukan pengukuran kembali terhadap objek yang sama. Reliabilitas suatu indikator dapat dilihat dari nilai cronbach's alpha $(\alpha)$. Jika nilai cronbach's alpha $(\alpha)$ lebih besar (>) 0,60 maka indikator dinilai reliabel, sedangkan apabila nilai cronbach's alpha $(\alpha)$ lebih kecil $(<)$ 0,60 maka indikator dinilai tidak reliabel. Secara keseluruhan hasil uji reliabilitas dapat dilihat pada tabel berikut:

Tabel 6

Uji Reabilitas

\begin{tabular}{lll}
\hline Variabel & $\begin{array}{l}\text { Crobach } \\
\text { Alpha }\end{array}$ & Keterangan \\
\hline Gaya Kepemimpinan & 0,872 & Reliabel \\
\hline Motivasi Kerja & 0,800 & Reliabel \\
\hline KepuasanKerja & 0,853 & Reliabel \\
\hline Kinerja Pegawai & 0,718 & Reliabel \\
\hline
\end{tabular}

Sumber : Hasil Olahan SPSS .

Berdasarkan Tabel di atas terlihat bahwa setiap variabel memiliki nilai masing- masing cronbach's alpha di atas 0,60. Dengan demikian dapat disimpulkan bahwa indikator-indikator yang terkait dengan variabel penelitian dinyatakan reliabel.Uji reliabilitas ini memberikan indikasi bahwa kehandalan kuesioner yang digunakan sebagai alat pengukur untuk tiap variabel termasuk pada kategori berkolerasi tinggi dan diterima.

\section{Uji Asumsi Klasik}

Sebelum melakukan pengujian hipotesis, terlebih dahulu akan dilakukanpengujian terjadinya 
penyimpangan terhadap asumsi klasik. Dalam asumsi klasik terdapat beberapa pengujian yang harus dilakukan, yakni

Uji Multikoliniearitas, Uji Heteroskedastisitas dan Uji Normalitas.

1. Uji Multikolinearitas

Uji multikolinearitas dilakukan untuk memastikan bahwa tidak ada korelasi sempurna antara variabel bebas yang satu dengan variabel bebas yang lain. Pengujian ini dilakukan dengan melihat nilai Variance Inflating Factor (VIF) dari hasil regresi. Jika nilai $>10$, maka terdapat gejala multikolinearitas yang tinggi. Hasil uji multikolinearitas dapat di lihat pada tabel sebagai berikut:

Tabel 7

\section{Uji Multikolinearitas}

\begin{tabular}{lcl}
\hline Variabel & VIF & \multicolumn{2}{l}{ Keterangan } \\
\hline $\begin{array}{l}\text { Gaya } \\
\text { Kepemimpinan }\end{array}$ & 9,272 & $\begin{array}{l}\text { Tidak ada } \\
\text { multikolinearitas }\end{array}$ \\
\hline Motivasi Kerja & 5,363 & $\begin{array}{l}\text { Tidak ada } \\
\text { multikolinearitas }\end{array}$ \\
\hline KepuasanKerja & 5,318 & $\begin{array}{l}\text { Tidak ada } \\
\text { multikolinearitas }\end{array}$ \\
\hline
\end{tabular}

Sumber : Hasil Olahan SPSS .

Dari Tabel di atas, terlihat bahwa VIF masing-masing variabel dalam penelitian ini menunjukkan angka yang lebih kecil dari 10. Hal ini berarti persamaan regresi pada penelitian ini tidak semua variabel bebas dari gejala multikolinearitas.

2. Uji Heteroskedastisitas

Uji heteroskedastisitas dilakukan untuk melihat apakah dalam model regresi terjadi ketidaksamaan varians residual dari suatu pengamatan yang lain. Uji heteroskedastisitas dilakukan dengan metode scatterplot.Jika pada titik - titik di dalam scatterplot terbentuk pola yang teratur (bergelombang, melebar, kemudian menyempit) maka telah terjadi gejala heteroskedastisitas. Untuk lebih jelas dapat dilihat pada gambar berikut:

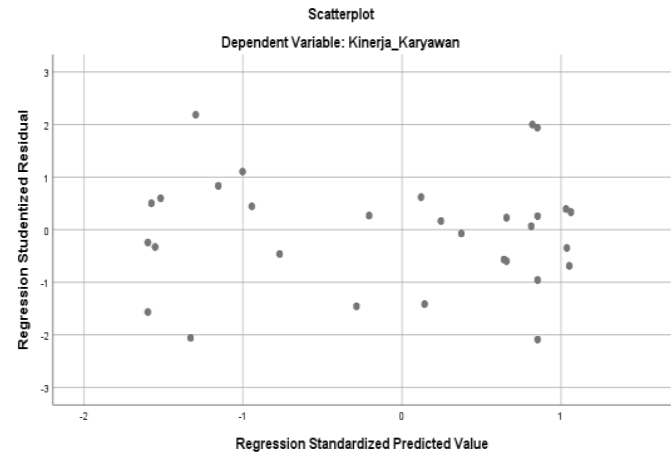

Dari gambar di atas, terlihat bahwa hasil scatterplot dari pengujian heteroskedastisidas menunjukkan bahwa data menyebar secara acak di atas maupun di bawah angka nol pada sumbu Regression Studentized Residual, artinya model regresi pada penelitian ini bebas dari gejala heteroskedastisitas.

3. Uji Normalitas

Uji normalitas adalah untuk mengetahui apakah dalam sebuah model regresi, variabel indenpenden dan dependen atau keduanya mempunyai distribusi normal atau tidak.Untuk mengetahui ada tidaknya normalitas dapat digunakan grafik Normal P-Plot of Regression Stand. Model regresi yang baik adalah bila distribusinya normal atau mendekati normal.Beberapa metode uji normalitas yaitu melihat penyebaran data pada sumber diagonal pada grafik normal $P$ $P$ plot of regression standardized residual atau dengan uji One Kolmogorov Smirnov.

\section{Gambar 3}

Uji Normalitas

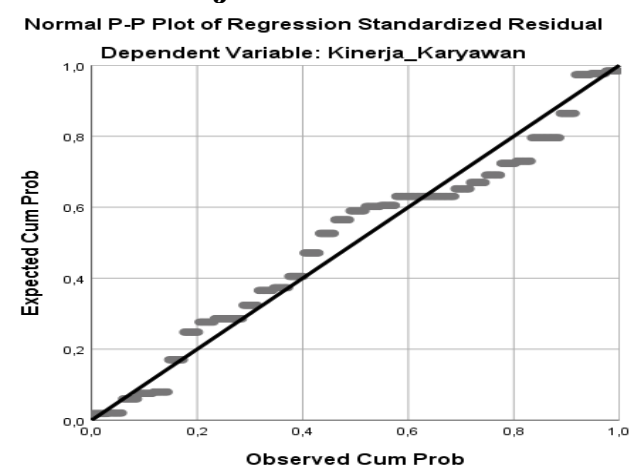

Sumber : Hasil Olahan SPSS 
Pada gambar di atas dapat dilihat hasil pengujian tersebut menunjukkan bahwa titik - titik berada tidak jauh dari garis diagonal.Hal ini

\section{Gambar 2}

\section{Uji Heteroskedastisitas}

Sumber : Hasil Olahan SPSS .

\section{Uji Analisis Regresi Berganda}

Dalam pengujian hipotesis penelitian ini menggunakan analisis regresi linear berganda untuk mengetahui besarnya pengaruh variabel gaya kepemimpinan, motivasi kerja dan Kepuasankerja terhadap kinerja pegawai.

\section{Tabel 8}

\section{Uji Regresi Linear Berganda}

\section{Coefficients $^{\mathrm{a}}$}

\begin{tabular}{|c|c|c|c|c|c|c|}
\hline \multicolumn{2}{|c|}{ Model } & \multicolumn{2}{|c|}{$\begin{array}{l}\text { Unstandardized } \\
\text { Coefficients }\end{array}$} & \multirow{2}{*}{$\begin{array}{l}\text { Standar } \\
\text { dized } \\
\text { Coeffici } \\
\text { ents } \\
\text { Beta }\end{array}$} & \multirow[t]{2}{*}{$\mathbf{T}$} & \multirow[t]{2}{*}{ Sig. } \\
\hline & & B & $\begin{array}{l}\text { Std. } \\
\text { Error }\end{array}$ & & & \\
\hline \multirow[t]{4}{*}{1} & (Constant) & 3,773 & 0,323 & & 11,667 & 0,000 \\
\hline & $\begin{array}{l}\text { Gaya } \\
\text { Kepemimpi } \\
\text { nan }\end{array}$ & 0,327 & 0,077 & 0,374 & 4,249 & 0,000 \\
\hline & $\begin{array}{l}\text { Motivasi } \\
\text { Kerja }\end{array}$ & 0,036 & 0,061 & 0,040 & 0,591 & 0,555 \\
\hline & $\begin{array}{l}\text { Kepuasan } \\
\text { Kerja }\end{array}$ & 0,435 & 0,059 & 0,492 & 7,395 & 0,000 \\
\hline
\end{tabular}

Sumber : Hasil Olahan SPSS

Dari tabel di atas, maka persamaan regresi linear berganda dalam penelitian ini adalah $: \mathrm{Y}=3,773+$ $0,327+0,036-0,435$. Persamaan regresi linear berganda tersebut dijelaskan sebagai berikut :

1. Dari regresi tersebut diperoleh nilai konstan sebesar 3,773 yang berarti variabel Gaya Kepemimpinan,Motivasi Kerja dan KepuasanKerja nilainya 0 atau tetap maka kinerja pegawai nilainya adalah 3,773.

2. Nilai koefisien Gaya kepemimpinan untuk variabel X1 sebesar 0,327 artinya jika variabel independen lain nilainya tetap dan gaya berarti menunjukkan bahwa model regresi tersebut sudah berdistribusi normal.

kepemimpinan mengalami kenaikan satu-satuan, maka kinerja pegawai akan mengalami peningkatan 0,327.

3. Nilai koefisien Motivasi Kerja untuk variabel X2 sebesar 0,036 artinya jika variabel independen lain nilainya tetap dan motivasi kerja mengalami kenaikan satu-satuan, maka kinerja pegawai akan mengalami kenaikan sebesar 0,036.

4. Nilai koefisien Kepuasan Kerja untuk variabel X3 sebesar 0,435 artinya jika variabel independen lain nilainya tetap dan komitmen mengalami penurunan satu-satuan, maka kinerja pegawai akan mengalami kenaikan sebesar 0,435.

\section{Uji Hipotesis}

\section{Uji Simultan (Uji F)}

Untuk menguji hipotesis penelitian ini yang menyatakan bahwa Gaya Kepemimpinan, Motivasi Kerja dan KepuasanKerja secara simultan memiliki pengaruh yang signifikan terhadap kinerja pegawai, maka perlu dilakukan pengujian secara simultan atau uji F. Model hipotesis yang diajukan antara lain:

Tabel 9

Uji Simultan ( Uji F)ANOVA ${ }^{\mathrm{a}}$

\begin{tabular}{lrrrrrr}
\hline Model & $\begin{array}{c}\text { Sum of } \\
\text { Squares }\end{array}$ & Df & $\begin{array}{c}\text { Mean } \\
\text { Square }\end{array}$ & F & Sig. \\
\hline 1 Regression & 1869,843 & 3 & 623,281 & 309,282 &, $000^{\mathrm{b}}$ \\
\hline Residual & 548,148 & 272 & 2,015 & & \\
\hline Total & 2417,991 & 275 & & & \\
\hline
\end{tabular}

a. Dependent Variable: Kinerja_Karyawan

b. Predictors: (Constant), Kepuasan_Kerja, Motivasi_Kerja, Gaya_Kepemimpinan

Sumber :Hasil olahan SPSS

Dari hasil pengujian secara simultan, diperoleh hasil $F_{\text {hitung adalah 309,282 }}$ sedangkan nilai $\mathrm{F}_{\text {tabel }}$ adalah 2,638 . Hal ini berarti $F_{\text {hitung }}>F_{\text {tabel }}$ dan nilai Sig $0,000<$ alpha 0,05. Jadi dengan demikian maka $\mathrm{H}_{0}$ ditolak dan $\mathrm{H}_{1}$ diterima artinya gaya kepemimpinan, motivasi kerja dan Kepuasan kerja secara silmutan berpengaruh terhadap kinerja pegawai. 
Uji t

Uji $\mathrm{t}$ digunakan untuk mengetahui pengaruh secara parsial variabel independent (gaya kepemimpinan, motivasi kerja, Kepuasan kerja) terhadap variabel dependen (kinerja pegawai). Berikut akan dijelaskan pengujian masingmasing variabel secara parsial

\section{Tabel 10}

\section{Hasil Uji t}

\begin{tabular}{lllll}
\hline & Pernyataan & $\begin{array}{l}\text { t } \\
\text { hitung }\end{array}$ & t tabel & Sig \\
\hline H1 & $\begin{array}{l}\text { Gaya } \\
\text { kepemimpinan } \\
\text { berpengaruh } \\
\text { terhadap kinerja } \\
\text { pegawai }\end{array}$ & 4,249 & 1,969 & 0,000 \\
\hline H2 & $\begin{array}{l}\text { Motivasi kerja } \\
\text { berpengaruh } \\
\text { terhadap kinerja } \\
\text { pegawai }\end{array}$ & & & \\
& & & \\
\end{tabular}

H3 $\quad$ Kepuasankerja $\quad 7,395 \quad 1,969 \quad 0,000$ berpengaruh terhadap kinerja pegawai

Sumber : Data Olahan SPSS

Uji Koefisiensi Determinasi $\left(\mathbf{R}^{\mathbf{2}}\right)$

Uji Determinasi $\left(\mathrm{R}^{2}\right)$ yaitu pengujian yang bertujuan untuk menilai berapa persen pengaruh dari variabel independent yang ada dalam model berpengaruh terhadap variabel dependen, sedangkan sisanya adalah pengaruh dari variabel lain.

Dari tabel dibawah ini menunjukkan nilai Adjusted $\mathrm{R}$ square sebesar 0,771. Hal ini berarti bahwa variasi kinerja pegawai dijelaskan oleh gaya kepemimpinan, motivasi kerja dan Kepuasan kerja sebesar ( $77,1 \%)$, sedangkan sebesar $(22,9 \%)$ dijelaskan oleh variabel lain yang tidak diteliti dalam model. Hasil uji koefisien determinasi dapat di lihat sebagai berikut:
Tabel 11

Uji Determinasi Model Summary ${ }^{b}$

\begin{tabular}{|c|c|c|c|c|c|}
\hline Model & $\mathrm{R}$ & $\begin{array}{l}\mathrm{R} \\
\text { Square }\end{array}$ & $\begin{array}{l}\text { Adjusted } \\
\text { R Square }\end{array}$ & $\begin{array}{l}\text { Std. } \\
\text { Error of } \\
\text { the } \\
\text { Estimate }\end{array}$ & $\begin{array}{l}\text { Durbin- } \\
\text { Watson }\end{array}$ \\
\hline 1 &, $879^{\mathrm{a}}$ & ,773 & ,771 & 1,41960 & 2,583 \\
\hline \multicolumn{6}{|c|}{ Predictors: $\quad$ (Constant), $\quad$ Kepuasan_Kerja } \\
\hline
\end{tabular}
diuraikan sebelumnya bahwa penelitian ini adalah untuk mengetahui pengaruh gaya kepemimpinan, motivasi kerja dan Kepuasankerja terhadap kinerja pegawai. Dengan demikian pembahasan yang telah dilakukan adalah untuk melihat signifikasi kontribusi pengaruh kepemimpinan, motivasi kerja dan Kepuasankerja terhadap kinerja pegawai.

Berdasarkan hasil uji Determinasi $\left(\mathrm{R}^{2}\right)$ terbukti bahwa variabel gaya kepemimpinan $\left(\mathrm{X}_{1}\right)$, motivasi kerja $\left(\mathrm{X}_{2}\right)$ dan Kepuasan kerja secara bersamasama berpengaruh cukup besar terhadap kinerja pegawai pada kantor notaris yang ada di sekitar Pekanbaru, sedangkan sisanya dipengaruhi oleh variabel lain yang bisa saja berupa adanya pekerjaan yang menarik dan memberi harapan, kondisi kerja, gaji, status, atau keamanan kerja, faktor lain ini sesuai dengan pendapat Sinungan (03:140).

Pengaruh Gaya Kepemimpinan, Motivasi Kerja dan Kepuasan Kerja Terhadap Kinerja Pegawai

Dari hasil pengujian secara simultan, diperoleh hasil bahwa nilai $F_{\text {hitung }} 309,282$ lebih besar dari $F_{\text {tabel }}$ 2,741 dan nilai signifikan 0,000 lebih kecil dari alpha 0,05 . Nilai koefisien determinasi $\left(\mathrm{R}^{2}\right)$ yang digunakan untuk menjelaskan proporsi variasi dalam variabel terikat yang dijelaskan oleh variabel bebas secara bersama-sama 
menunjukkan angka sebesar 0,771. Hal ini berarti bahwa variasi kinerja pegawai dijelaskan oleh gaya kepemimpinan, motivasi kerja dan Kepuasankerja sebesar $77,1 \%$, sedangkan sebesar 22,9\% dijelaskan oleh variabel lain yang tidak diteliti dalam model ini. Dari kedua pengujian diatas diperoleh kesimpulan bahwa gaya kepemimpinan, motivasi kerja dan Kepuasan kerja memiliki pengaruh secara simultan terhadap kinerja pegawai pada kantor notaris yang ada disekitar Pekanbaru.

Pengaruh Gaya Kepemimpinan Terhadap Kinerja Pegawai

Dari hasil penelitian ini, menunjukkan bahwa gaya kepemimpinan berpengaruh dan signifikan terhadap kinerja karyawan sebesar 4,249 dengan 0,000 pada angka signifikan.Ini merupakan faktor yang dianggap setuju oleh responden mengenai faktor untuk meningkatkan kinerja pegawai pada kantor Notaris yang ada disekitar Pekanbaru. Mendukung penelitan sebelumnya yang dilakukan oleh Hapid dan Acep Rochmat Sunarwan (2014) membuktikan bahwa gaya kepemimpinan memiliki pengaruh yang paling kuat terhadap kinerja karyawan pada PT. Financial Multifinance

Pengaruh Motivasi Kerja Terhadap Kinerja Pegawai

Hasil pengujian menunjukkan bahwa nilai $t_{\text {hitung }}$ untuk variabel seleksi 0,591 lebih kecil dari $t_{\text {tabel }} 1,969$ atau nilai signifikan 0,555 lebih kecil dari alpha 0,05. Hal ini berarti bahwa motivasi kerja tidak berpengaruh dan signifikan terhadap kinerja pegawai. Tidak senada dengan Bryan Johannes Tamp (2014) bahwa gaya kepemimpinan dan motivasi kerja berpengaruh positif terhadap kinerja karyawan.

\section{Pengaruh Kepuasan Kerja Terhadap Kinerja Pegawai}

Hasil pengujian menunjukkan bahwa nilai $t_{\text {hitung }}$ untuk variabel seleksi 7,395 lebih kecil dari $t_{\text {tabel }} 1,969$ atau nilai signifikan 0,000 lebih kecil dari alpha 0,05. Hal ini berarti bahwa Kepuasan kerja berpengaruh dan signifikan terhadap kinerja pegawai. Penelitian ini sejalan dengan penelitian terdahulu yang dilakukan oleh Harlie (2011) membuktikan bahwa Kepuasan kerja dan pengembangan karir berpengaruh positif secara baik dan simultan terhadap kinerja pegawai.

\section{PENUTUP}

\section{Kesimpulan}

1. Gaya Kepemimpinan berpengaruh dan signifikan terhadap kinerja karyawan pada kantor notaris yang ada di Pekanbaru, artinya terdapat hubungan yang signifikan antara gaya kepemimpinan dengan kinerja karyawan. Hal ini ditunjukkan gaya kepemimpinan dapat mempengaruhi kinerja karyawan dalam bekerja pada kantor notaris yang ada di Pekanbaru.

2. Motivasi Kerja tidak berpengaruh dan tidak signifikan terhadap kinerja karyawan. Motivasi kerja tidak berdampak langsung terhadap organisasi itu sendiri. Tidak signifikannya variabel ini dapat disebabkan motivasi kerja karyawan masih wajar sehingga tidak mempengaruhi kinerja dari karyawan kantor notaris yang ada di Pekanbaru.

3. Kepuasan Kerja berpengaruh dan signifikan terhadap kinerja karyawan pada kantor notaris yang ada di Pekanbaru. Dari hasil pengujian secara simultan gaya kepemimpinan, motivasi kerja dan Kepuasan kerja berpengaruh secara simultan 
terhadap kinerja karyawan di Kantor Notaris yang ada di Pekanbaru,

\section{Saran}

1. Pengaruh variabel gaya kepemimpinan, motivasi kerja dan Kepuasan kerja masih sangat kecil terhadap kinerja karyawan, oleh karena itu bagi peneliti yang akan meneliti dengan tema yang sama, sebaiknya menambah jumlah variabel bebas (independen), agar hasil penelitian dapat lebih baik lagi dalam membuktikan hipotesis.

2. Agar hasil penelitian ini dapat digeneralisasi, sebaiknya penelitian yang akan datang meneliti semua kantor notaris dengan periode pengamatan yang lebih panjang.

3. Bagi peneliti selanjutnya yang berminat dengan tema yang sama dengan penelitian ini disarankan untuk menggunakan metode pengambilan sampel yang lain dengan jumlah sampel yang lebih besar, dan dapat juga diteliti apakah variable gaya kepemimpinan, motivasi kerja dan Kepuasan kerja berpengaruh terhadap kinerja pegawai atau produktifitas kerja, maupun kepuasan kerja yang diaplikasikan pada organisasi lain selain organisasi yang bergerak dibidang kemasyarakatan.

\section{DAFTAR PUSTAKA}

A. A. Anwar Prabu Mangkunegara (2011). Manajemen Sumber daya manusia Perusahaan. Bandung: PT.Remaja Rosdakarya.

Agwu, M. (2012). Impact of Employees Safety Culture on Organisational Performance in Shell Bonny Terminal Integrated Project (BTIP): European Journal of Business and Social Sciences, 1(5):70-82.

Agwu, M. (2013). Impact of Fair Reward System on Employees Job Performance in Nigerian
Agip Oil Company Limited PortHarcourt: British Journal of Education, Society \& Behavioural Science 3(1): 47-6.

Brahmasari dan Suprayetno, (2008). Pengaruh Motivasi Kerja, Budaya Organisasi Terhadap Kepuasan Kerja Karyawan serta Dampaknya pada Kinerja karyawan (Studi kasus pada PT. Pei Hai International Wiratama Indonesia), Journal Manajemen dan Kewirausahaan. 10(2).

Bryan, (2014). Pengaruh Gaya Kepemimpinan dan Motivasi terhadap Kinerja Karyawan pada PT. Bank Negara Indonesia, Tbk (Regional Sales Manado), Jurnal Acta Diurna. 3(4).

Chintalloo, S \& Mahadeo, J. (2013). Effect of Motivation on Employees' Work Performance at Ireland Blyth Limited: Proceedings of 8th Annual London Business Research Conference Imperial College, London, UK.

Galup, S. D., Klein, G., \& Jiang, J. J. (2008). The impact of job characteristics on is employee satisfaction: A comparison between permanent and temporary employees. Journal of Computer Information Systems, 48(4), 58-68.

Ghozali, Imam. (2011). "Aplikasi Analisis Multivariate Dengan Program SPSS". Semarang: Badan Penerbit Universitas Diponegoro.

Harlie, (2012). Pengaruh Disiplin Kerja, Motivasi dan Pengembangan Karier terhadap Kinerja PNS pada Pemkab Tabalong diTanjung Kalimantan Selatan. Jurnal aplikasi manajemen, 10(4). 
Hasibuan, Malayu, S.P. (2008). Manajemen Sumber Daya Manusia. Jakarta: Bumi Aksara

Kartono, Kartini. (2008). Pemimpin dan Kepemimpinan: Apakah Kepemimpinan Abnormal itu ?". Jakarta: Rajawali Perss

Kuvaas, B. \& Dysvik, A. (2009), "Perceived nvestment in Employee Development, intrinsic Motivation and Work Performance', Human Resource Management Journal, 19(3) : 217-236.

Luthans, F. (2005). Organizational Behavior. New York: McGrawhill.

Lee. H. Y., \& Ahmad, K. Z., (2009). The moderating effects of organizational culture on the relationships between leadership behaviour and organizational commitment and between organizational commitment and job satisfaction and performance. Leadership\& Organization Development Journal, 30(1):53 86.

Marthis Robert L. dan Jackson Jhon H. (2006). Human Resource Management, alih Bahasa. Jakarta: Salemba Empat

Nurlaila, (2010). Manajemen Sumber Daya Manusia I. Penerbit LepKhair.

Purwati, A., \& Satria, H. (2018). Pengaruh Perekrutan, Motivasi, Dan Pelatihan Terhadap Kinerja Karyawan Pada CV. Skala Sport Pekanbaru.

PROCURATIO (Jurnal Ilmiah Manajemen), 5(4),418-429. Retrieved from http://ejournal.pelitaindonesia.ac. id/index.php/procuratio/article/vi $\underline{\text { ew/275 }}$
Rahman, S., Purwati, A., \& Yazid, M. (2018). Pengaruh Motivasi, Kepuasan Kerja, Dan Disiplin Kerja Terhadap Kinerja Karyawan Sabrina City Hotel Pekanbaru. KURS (Jurnal Akuntansi Kewirausahaan dan Bisnis), 2(2), 138-152. Retrieved from http://ejournal.pelitaindonesia. ac.id/index.php/KURS/article/ view/284

Rivai, Veithzal. (2009). Kepemimpinan dan Perilaku Organisasi. Jakarta: PT Raja Grafindo, Persada.

Robbinss Stephen P., (2011). Organizational Behavior (Terjemahan) Jilid 1, Edisi Kedelapan. Jakarta: PT. Bhuana Ilmu Populer

Sarjono, Haryadi dan Winda Julianita. (2011). SPSS vs LISREL: Sebuah Pengantar, Aplikasi untuk Riset. Jakarta: Salemba Empat

Scroggins, W. (2008). The relationship between employee fit perceptions, job performance, and retention: Implications of perceived fit. Employee Responsibilities \& Rights Journal, 20(1):57-71.

Sugiyono. (2013). Metode Penelitian Bisnis. Bandung: Alfabeta.

Sudarmo. (2015). Pengaruh Gaya Kepemimpinan, Motivasi, dan disiplin kerja terhadap kinerja karyawan PT. Empat Enam Jaya Abadi

Sugiyono. (2013). Metode Penelitian Bisnis. Cetakan Keduabelas, Bandung: Alfabeta

Yang, H. (2008). Efficiency Wages and Subjective Performance Pay, Economic Inquiry, 46(2):179196.

Wicker, D. (2011). Job Satisfaction: Fact Or Fiction. Author House. 